DOI: 10.20472/IAC.2018.044.026

\author{
SERGEY LYUBICHANKOVSKIY \\ Orenburg State Pedagogical University, Russian Federation \\ ELENA GODOVOVA \\ Orenburg State Pedagogical University, Russian Federation
}

\title{
RUSSIAN EMPIRE'S POLICY OF ACCULTURATION FOR CHRISTIAN SECTARIANS (XIX - THE BEGINNING OF THE 20TH CENTURIES)
}

\begin{abstract}
:
This research is about features of a policy of acculturation for Christian sectarians in the territory of Orenburg region of XIX - the beginnings of the 20th centuries. The subject of the relationship of the Orthodox Russian Empire with Christian sectarians repeatedly rose in modern scientific literature. However the situation in the huge suburban Eurasian region on the border of Europe and Asia - the Orenburg region - wasn't analyzed systemically. The purpose of our research - to study a question on the basis of primary sources from the local archive. The government sought to provide stability in the Orenburg province and incorporation of the region in the structure of the Empire by means of acculturation policy. This policy concerned not only the Muslims living here but also Christian sectarians. Christian sectarianism in a mass look has appeared in the Orenburg region from the second half of the 19th century. The activity of Russian Orthodox Church in the Orenburg diocese has been directed to the identification of sectarians and "their return to a bosom of a church" through explanations and education. If efforts of the church didn't result in desirable results, then more drastic measures with an involvement of the Orenburg provincial administration and police were taken. As a result in the region, steady process of formal transition to Orthodoxy at a secret observance of former ceremonies was supported. The factor complicating work of the Orthodox Church with sectarians in the territory of the Orenburg province was her status of the territory in large quantities accepting immigrants among whom sectarians have been presented in a large number. The research is executed at the expense of a grant of the Russian Science Foundation (project No. 17-18-01008) in the Orenburg State Pedagogical University.
\end{abstract}

\section{Keywords:}

History of acculturation, Identity, Christian sectarianism, Russian Empire

JEL Classification: N90, Z12 


\section{Introduction}

The Orenburg province was inhabited for two centuries. The government sought to ensure stability in the region and the incorporation of the South Urals into the empire by changing the ratio of the number of ethnic groups. Therefore, the government transferred to the newly developed lands mainly state-owned peasants of the Orthodox faith. However, along with this, there has always been a so-called "runaway" colonization. Among the runaway peasants there were sectarians.

\section{Regional structures to combat Christian sectarianism}

According to historical data, Christianity in the Southern Urals appeared with the conquest of Kazan in 1552 and the annexation of Bashkiria in 1556 and the Russian movement that began in connection with this on the southeastern outskirts of Russia. Actually, Christian secession in one of the earliest forms of Khlysty, Skopje, etc. in the mass form appeared in the Orenburg region from the second half of the XIX century. However, the first manifestations of the struggle between civil and spiritual power and sectarianism were noticeable in the first half of the 18th century. and are associated with the activities of the Kazan Archbishop Luke Konashevich. With his death, this activity was suspended until the first quarter of the 19th century. In 1813, His Eminence Augustine "informs" the number of dissenters and sectarians in the dioceses and orders to increase "pastoral care" in relation to them. Since the 1830's. on sectarianism draws attention and civil authority. In the 1840-1850's. under the leadership of VA. Perovski measures of influence begin to intensify. In 1847, the Secret Advisory Committee was established in Ufa, and in 1849 Zlatoust Resurrection monastery was opened in order to prevent sectarianism and schism. In 1854, the first priests were appointed to the Chelyabinsk district for the purpose of missionary activity. In $1855-1856$ years. The teaching program of the Ufa Spiritual Seminary introduces the teaching of schism and sectarianism. However sectarian trends continued to increase, especially under the influence of permanent resettlement.

With the separation of the Orenburg diocese from Orenburg-Ufa in 1859 in Orenburg, an independent secret-advisory committee was established, which lasted until 1865. During this period, activity against sectarians and schismatics again weakens. Her revival begins with the activity of His Grace Viniyamin II, who introduced in 1882 in Orenburg, and then in the entire diocese, the so-called "public conversations" with schismatics and sects. To this end, they invited the Perm priest Lukanin and the Synodal missionary Fr. Xenophon Kryuchkov, who was a priest at the newly-unanimous church in Orenburg. $O$. Xenophon visited almost the whole territory of the Orenburg diocese, in particular Chelyabinsk district and the Ural region.

After the Kazan Cathedral of the Hierarchs, who worked out various measures against schism and sectarianism, in 1886 a question was raised about the establishment in the 
diocese of special posts for district missionaries, which were then opened in Orenburg (1887), Chelyabinsk (1891) and the Urals (1894) districts. In 1896 the post of diocesan missionary was established. His duties included monitoring the parishioners of the ward under his supervision, identifying sectarians and exhorting them, as well as writing reports for the Orenburgh Spiritual Consistory about the presence of sectarians in the parish, their number, occupation, faith, etc.

\section{The scale of the spread of sectarianism in the Orenburg diocese}

The scattered information does not allow us to determine the extent of the spread of sectarianism. So according to a report dated February 22, 1898, the priest Alexander Kamshlovsky, it was reported: "... a sect in the families of Orthodox Cossacks began to exist since 1898, when there were also gatherings of whips ... in 4-5 houses of Cossacks ... about these gatherings were reported ... to the authorities, and in the same year of 1898. On the orders of the Diocesan authorities, a missionary, M.G. Golovkin, for exhortation of the Cossacks and Cossacks who were lost in the Khlysty sect, who were 12 people ... ". The author claims that parishioners regularly attend church services: "... the temple is visited ... constantly ... and receive communion ...". At the same time, there were separate cases of charges in the homes of residents for reading church books mistaken for meetings of sectarians whose names were given according to the names of the owners of houses: "... following your order of February 22, 1898, No. 97, received by me on March 2 , with respect to the sects "spiritual kupriyanovskaya" and "carnal ephremovka" in the village of Cherepanovka. for the first time I hear and wonder ... I have not had such sects in the parishes, because perhaps some of the parishioners from the village of Cherepanovka gathered in the house of Kupriyan Yartsev, where they read books of spiritual content and in the house of Efrem Trutnikov also read on holidays and the most part of parishioners "is going to."

Another reason for the spread of sectarianism, according to the Orenburg Spiritual Consistory and the police, was the resettlement of peasants from one farm to another. So, in 1886, the case was considered of a peasant Grigory Zagribailov, who was accused by the Orenburg Chamber of Criminal and Civil Court of the distribution of molokanstva. The resolution stated that "... the last year passed from the city of Orenburg to the farm of Donguz, a peasant from the Saratov province ... Grigory Ivanovich Zagribailov, who is a follower of the Molokan sect, and now distributes this sect among the right-glorious farmers, now from the number of 9 families of the farm seduced $4 \ldots$...

Often sectarianism was spread violently among relatives or friends: "on the night of February 14,1886 , a peasant from the village of Kalinin in the Orenburg district Fedor Fistapiev and his wife Olga began to persistently incline their sixteen-year-old daughter Anna to accept heresy heresy .... despite the exhortations and persuasion, the daughter stubbornly refuses to skopchestva ... began to persuade her to take a scrap of the peasants who had brought from the village of Novo-Nikitino Irina Astrakhanskaya, who 
thanks to sectarianism has the gift of prophet, but from this Anna refused and learned from a secret conversation with her parents that they are going to perform a rite over her ... ".

\section{Pretending to be Orthodox ...}

To avoid persecution of the Russian Orthodox Church, the sectarians voluntarily accepted Christianity, attended the church and performed Christian rites. The priests of the parishes entrusted to them often revealed such sectarian formations, which they ascertained in their reports to the Orenburg Spiritual Consistory. In particular, an example of this can be the report of the priest of the Gorodishchensky parish dated October 12, 1897, in which he accuses the sectarians of the following: "... Meetings at night, and not during the day ... that the need to arrange gatherings in hidden dens, to be locked from the eyes of strangers, if they are true children of the Holy Apostolic Church and not hypocritical sons of their fatherland, then why do they hide their deeds and their deeds from them from the clergy and government, by what right do they arrange gatherings without permission and control of local spiritual and the authorities of the state .... " Also, in order to avoid persecution and punishment, both from the Russian Orthodox Church and from the government authorities, they tried not to oppose tax levies and serving various duties.

This report can serve as evidence of the existence of "whips" in the Orenburg province in the specified period: "... not eating meat, wine, tobacco, rejecting the marriage life, most of them satisfy their natural sexual needs in an unnatural way, which is blasphemously called in their language: "Christlike love" .... on the basis of the foregoing ... the persons caught by the ataman of the Gorodishchensky stanitsa in the house of the Gorodishchensky Cossack are: "whips" (they are people of God and allegedly spiritual ristiane), if not in the full sense of the word, there is no doubt proselytes Khlysty heresy with all the harmful attributes nefarious Khlysty sects and harmful to religion, the state, society and morality".

\section{The views of sectarians on Russian society}

The priests who received information about the sectarians reported this to the authorities, and also independently undertook actions to "convince" the people. At the same time, there is a clear tendency to understand the causes of "delusions". Thus, archival materials for 1897 according to the Gorodishchensky stanitsa indicate that the sectarians "abused chiefs", calling them "evil wolves", "bloodthirsty beasts", "antichrists", etc. , this gives grounds to believe that officials or superiors sometimes exceeded their authority, and the result of this was the negative attitude of the population.

But despite such seemingly detached and distrustful attitude toward the Church, many converting sects often confused sectarian and Orthodox faith, urging priests to serve in their meetings. That is, the sectarians sought to attract other people into their ranks, as 
well as to form their own ritual. So, the residents of the village Trebiatsky and Fershampenois asked the local priest "... to them, to the place of sacrifice with the cross and the icons to serve a prayer ... and to drink with holy water all the food. The purpose of the sacrifice is that the Lord would give them rain and not deprive them of hail ... ".

\section{Missionaryism of sectarians in the Orthodox environment}

The efforts of the Russian Orthodox Church led to the fact that people themselves converted to Orthodoxy, renouncing the sectarian teachings. In some years their number reached 800 people a year. However, often such transitions were only an appearance and the ability to escape from missionary persecutions or successfully marry / marry. An example is the case considered in the Orenburg Uyezd Police Department for 1896: "... She, three years ago at the behest of her parents, married a burgess of the mountains. Novouzensk Mikhail Frolov Ivanov, who belonged to the Molokan sect earlier and only a month before the marriage with her who had gone to Orthodoxy. A month before the marriage, he ... took communion ... but soon after the wedding he left to fulfill the duties of Orthodox Christian, did not go to church, observe fasts and Christian rites and apparently again moved to the Molokan sect, which he tried to seduce and her ".

Similar "preachers" were repeatedly sent "to the people" in order to attract as many people as possible to their side, often marrying to create a "favorable image" and having several families in different villages. So, for example, in the investigation file, examined in the Orenburg Uyezd Police Department on September 18, 1896, it was said that "... her husband, as she learned, has a wife in Novovuzensk and her child and not long before marriage with her has a wife and from her two daughters in lletskaya Protection .. ".

Another way to conceal sectarian activity was the establishment of various societies whose meetings were closed and whose activities were not questioned. In particular, in the report of the priest Nikolai Balalaev, sent to the Bishop of Orenburg and the Urals, it was said that "members of the sobriety society belong to Tolstoy. The facts, to which the priest of the Ryov community referred, were confirmed, but only by the testimony of those people, from whose words he wrote the statement. Deacon Sharonov really showed that he was offered the Gospel of Tolstoy. Mintyev said that Chalusov was indeed a member of the society, that he doubted the image of the descent of Jesus Christ to hell. From the documents of the church it can be seen that the members of the society were not at St. Volodya's during the service in the Lbischensky parish of Ryouev .... Nevertheless, none of this speaks for the fact that members of the sobriety society with. Lbischevo belong to Tolstoy. To be fair, not only the deacon Sharonov, but Valdimir himself, can hardly correctly define the essence of Tolstoy's teaching. The possible thing that the members of the society heard about Tolstoy, a few got acquainted with his works, even unprintable, but this does not in the least prove the adherence of the whole society to Tolstoy. I say the possible thing that the members of society read Tolstoy's works about themselves, and as soon as they saw what was behind them, that it turned out bad consequences and 
stopped reading it, at least nothing is visible in the propaganda and the inhabitants do not yet understand, what is Tolstovism; To admit to their own and their near intellectual development they can not digest the teachings of Tolstoy .... ".

However, with all such efforts, the total number of sectarians in the Orenburg province did not decrease, and very often a picture of its distribution was observed. In particular, a lot of Molokans moved from the Kherson province.

\section{Sectarians and decree on religious tolerance in 1905}

On April 17, 1905, under the influence of the development of the democratic process in the Russian Empire during the reign of Nicholas II, the government issued a decree "On Strengthening the Foundations of Tolerance", which essentially changed the legal status of "heterodox" and "heterodox" confessions, including and in the Orenburg province. By this decree, the rights of sectarian communities that were not of a "fanatical nature" were significantly expanded. Almost in all respects, in particular in possession of property, in the right to build prayer houses, to build monasteries, monasteries, to print liturgical books, teach their children the "Law of God", to conduct metric books, they were equalized with the Orthodox Church. The previous restrictions for sectarians on their admission to the civil service were abolished. However, the sectarian clergy did not receive the right to the officially recognized use of spiritual ranks and titles, which was used by the Armenian-Gregorian, Armenian-Catholic, Lutheran and reformist clergy. The decree made essential changes in the legal order of the change of religion. The old prohibitions and restrictions on the transition from one Christian-recognized confession to another have been lifted. The document did not mention the possibility of joining the "heterodox" to one of the non-Orthodox Christian communities, but in practice, after the issuance of the decree, such transitions did not encounter any obstacles from the state authorities of the Orenburg province. It was legalized to return a "convert of the Orthodox" or "heterodox" Christian at his request into his past faith. Relative freedom in the choice of religion was presented.

\section{Conclusion}

Thus, in the second half of the XIX - beginning of the XX century, the activities of the Russian Orthodox Church in the Orenburg diocese were aimed at identifying sectarians and "returning them to the bosom of the church" through explanations and enlightenment. If the efforts of the Church did not lead to the desired results, then more stringent measures were taken with the involvement of the Orenburg provincial administration and the police. As a result, the region sustained a steady process of formal transition to Orthodoxy with the secret observance of the old rites. The factor that made the work of the Orthodox Church difficult with sectarians in the territory of the Orenburg province was its status of a territory that massively received settlers, among whom sec- tons were represented in large numbers. 


\section{Acknowledgment}

The research is executed at the expense of a grant of the Russian Science Foundation (project No. 17-18-01008) in the Orenburg State Pedagogical University.

\section{Reference}

EFIMENKO, M.N. (1999). Missionary Activity of the Russian Orthodox Church in Orenburg Province (18th19th century). In Influence of Christian Traditions on the Cultural Life of Orenburg Region. Materials of the scientific - practical conference devoted to the 2000th anniversary of Christianity. Orenburg, P. 44 .

KAMZINA, A.D. (2004). Old Believers as an Object of Missionary Activity of the Russian Orthodox Church in Orenburg diocese (1859-1917) (Dissertation of Candidate of Historical Sciences). Orenburg. P. 127.

LYUBICHANKOVSKIY, S.V. (2014). Development of Orthodox Monasteries in the Orenburg Region in the Context of Post-reform Modernization. In Proceedings of the Samara Scientific Center of the Russian Academy of Sciences. Vol.16. No.3. pp .392-396.

PREOBRAZHENSKY, I. (1897). The Native Church According to Statistical Data from $1840-1841$ to 1890 - 1891. St. Petersburg, P. 46.

APKARIMOVA E.Y. (2004). Orthodox Brotherhoods in the Southern Urals in the Late 19th - Early 20th Centuries. The Ural Biriukov Readings: Col. scientific articles. Issue 2. From the history of the Southern Urals and Russian regions. Chelyabinsk. P. 374.

CHERNAVSKY N. (1900). Orenburg Diocese in the Past and the Present. Issue 1. Orenburg: Printing house Orenburg. Dukhov. Consistories. P. 341.

DORSKAYA A.A. (2001). Freedom of Conscience in Russia: the Fate of Bills in the Beginning of the 20th Century (Monograph). St. Petersburg. P. 59.

NIKOLAEV E.A. (2006). Cultural and Historical Transformations of Orthodoxy and Islam in the Public Discourse of Russia. (Dissertation of Doctor of Historical Sciences). Ulan-Ude. P. 47. 